\title{
Social Sanction: Naked Parade and Vigilantism as Legal Violation Criminal Law Perspective and Human Rights
}

\begin{tabular}{|c|c|}
\hline \multicolumn{2}{|c|}{ Kuswardani $^{1}$, Sunaryo ${ }^{2}$} \\
\hline $\begin{array}{l}{ }^{1} \text { Faculty of Law, Muhamma } \\
{ }^{2} \text { Faculty of Law, University of Lan }\end{array}$ & $\begin{array}{l}\text { yah University of Surakarta, Indonesia, Email: } \\
\text { us283@ums.ac.id } \\
\text { ing, Indonesia, E-mail: sunaryo1960@fh.unila.ac.id }\end{array}$ \\
\hline ibmitted: October 5, 2020; Revie & November 15, 2020; Accepted: December 7, 2020 \\
\hline Article Info & Abstract \\
\hline $\begin{array}{l}\text { Keywords: } \\
\text { Naked Parade, Street Justice Social } \\
\text { Sanction. } \\
\text { DOI: } \\
\text { 10.25041/fiatjustisia.v15no2.1934 }\end{array}$ & $\begin{array}{l}\text { Naked parade and vigilantism are social sanctions } \\
\text { or informal sanctions imposed by the community for } \\
\text { acts deemed contrary to the local community's } \\
\text { norms. These sanctions include vigilante action, } \\
\text { which breaks the law. This paper aims to explain } \\
\text { social sanctions (naked parade) from a legal } \\
\text { perspective, particularly studied from human rights } \\
\text { and criminal law. The study uses a normative } \\
\text { approach so that the data sources include legal } \\
\text { documents, references, and journals relevant to the } \\
\text { problem being studied. The data analysis using } \\
\text { consists of human rights principles and criminal } \\
\text { law. The study results show that naked parade and } \\
\text { vigilante as social sanction contradict human rights } \\
\text { principles (liberty, non-discrimination, dignity, } \\
\text { humanity, and equity). This act is also a criminal } \\
\text { act, considering that the criminal law functions to } \\
\text { protect the legal rights of individuals, the } \\
\text { community, and the state. There is no explicit } \\
\text { formulation of naked parade in the Penal Code } \\
\text { (KUHP) or regulations outside the Penal Code. It is } \\
\text { necessary to formulate it explicitlyas an act thatcan } \\
\text { be punished. }\end{array}$ \\
\hline
\end{tabular}

\section{A. Introduction}

Social sanctions in the naked parade and/or vigilantism intended by the local community as social control against disturbances in security and public order. Another term, naked parade, is often equated with persecution or vigilantism. According to the Black Law Dictionary, the meaning of each is as follows persecution is violent, cruel, and unjust treatment directed toward a person or group of persons because of their race, religion, sexual orientation, politics, or other beliefs. Vigilantism is the act of a citizen who takes the law 
into his or her own hands by apprehending and punishing suspected criminals. ${ }^{1}$ In essence, persecution and vigilante have an identical concept as violent acts to oppress other people or certain community groups. The community gives this sanction to the perpetrators of the violations of public order. So the social sanction for naked parade can be said as another form of vigilante to punish the actions of someone who has disturbed the security and order of the local community. David Weisburd said that the act an agent of community social control, the goal is to create security and order in the environment. ${ }^{2}$ This form of social control in the legal literature is commonly referred to as the act of self-judgment or eigenrichting (Dutch), in English street justice or vigilantisms. Several previous studies such as Nicole E. Hass, et.all, ${ }^{3}$ Tina Asmarawati, ${ }^{4}$ Tonny Rompis, ${ }^{5}$ Andrew Silke, ${ }^{6}$ show that these social sanction (parade naked and vigilante) is due to public distrust of law enforcers, especially police.

Public sanctions as a form of social control are different from those in western countries such as Europe. Community sanctions in Europe work on probation and parole, so instead of the community imposing sanctions on perpetrators, the imposition of permanent sanctions by judicial or administrative institutions. The definition of community sanction is "Sanctions and measures which maintain suspects or offenders in the community and involve some restrictions on their liberty through the imposition of conditions and/or obligations. And ways of enforcing a sentence of imprisonment outside a prison establishment."7 Community sanctions in Europe are the same as community supervision in America. ${ }^{8}$

However, in fact, the social sanctions between the naked parade and vigilante are different. The penalty for this naked parade is by parading the

\footnotetext{
${ }^{1}$ Bryan A. Graner, Black Law Dictionary (Paul Mint: West Publishing, 2004), 3617\&3852.

2 David Wiesburd, "Vigilatism as Community Social Control: Developing a Quatitative Criminological Model", Journal of Quatitative Criminology 4, (1988): 137-153, DOI: 10.1007/BF01062870

3 Nicole E. Hass, "Public support for vigilantism, confidence in police and police responsiveness", Policing and Society Journal, Vol 24, No 2, (2014): 224-41, DOI: 10.1080/10439463.2013.784298.

${ }^{4}$ Tina Asmarawati, "Perspektif Hukum Dalam Main Hakim Sendiri”, Jurnal Nurani Hukum 3, no. 1 (2020): 45-57.

5 Tonny Rompis, "Kajian Sosiologi Hukum Tentang Menurunnya Kepercayaan Masyarakat Terhadap Hukum dan Aparat Penegak Hukum Di Sulawesi Utara", Jurnal Lex Crimen 4, no. 8 (2015): 166-176.

${ }^{6}$ Andrew Silke, "Dealing Vigilantism Dealing with Vigilantism: Issues and Lessons for the Police", The Police Journal: Theory, Practice and Principles 74, (2001): 120-133, DOI: 10.1177/0032258X0107400204.

7 Vivian Geiran and Ioan Durnescu, Implementing Community Sanctions and Measures (Europe: the Directorate General Human Rights and Rule of Law, 2019), 7.

${ }^{8}$ Cecelia Klingele, "Rethinking The Use Of Community Supervision", Journal of Criminal Law and Criminology 103, no. 4 (2013): 1015-1070, DOI: 10.2139/ssrn.2232078.
} 
perpetrator of the act half-naked, without hurting the perpetrator's body, while vigilante, acts committed by the community (certain groups) by way of violence, this can cause injury or loss of life. The phenomenon of these two social sanctions can be found in the coverage of various print and online media, such as the sanction for the naked parade as happened (1) The case of naked parade to a 12-year-old boy named AJ who suspected stole Halim's jacket which was drying in the terrace house in Kampung Rawa Bambu, Harapan Jaya Village, North Bekasi District, on Sunday, March 8, 2018. AJ was beaten and stripped naked, then paraded use motorcycle..$^{9}$ (2) (2) The case of the parade around the village occurred in Sanganom Village, Nguling District, Pasuruan Regency, East Java, August 26, 2019. This case concerns a police officer who is suspected of being obscene with a married village midwife, being paraded around the village by local residents. ${ }^{10}$

Examples of social vigilante sanctions among others the case of people beatings that occurred on August 7, 2017, against a man named Muhammad Al Zahroh alias Zoya, who was accused of stealing a loudspeaker (amplifier) at the Al Hidayah Mushola, Pondok Cabang Empat, Babelan District, Bekasi Regency, West Java. The people do beating and burning alive against Joya. ${ }^{11}$ Even though it differs in the fact of its implementation between those two social sanctions, but those two sanctions cause suffering, only naked parade is more psychic, while for vigilantism, the consequences for physical suffering can lead to death. So, both of them cause harm and loss, and in fact, have an impact on the balance of distractions in the community.

A lot of these cases raises concerns because these acts are legally contradictory, even though the community believes that these actions are conducted to maintain order in the community, because these acts could cause both material and immaterial losses, such as injuries or disabilities whole life or until the loss of other person's life. This action is actually prohibited by law, especially criminal law (material/substantive). However, criminal law does not formulate explicitly in the formulation of its regulations by using the word "act of vigilantism" or by the word "sanction of the naked parade", both inside of Penal Code and outside of the Penal Code. Thus, the people who are unfamiliar with the law do not understand it if that act is a criminal act. In fact, there are forms of action in the Criminal Code, such as assault, murder and others, these acts are usually a manifestation of social sanctions. However, the community does not yet understand if it can be forced on their actions.

\footnotetext{
9 http://harianumumsinarpagi.com/2018/04/13/korban-persekusi-bocah-berusia-12-tahun-dibekasi-dipukuli-lalu-di-arak-bugil-lantaran-dituding-curi-jaketr/, Accessed on September, 19, 2020.

${ }^{10} \mathrm{https}: / /$ www.kanalinspirasi.com/diduga-mesum-dengan-bidan-bersuami-oknum-polisidiarak-keliling-kampung/, Accessed on September, 19, 2020.

${ }^{11}$ https://www.liputan6.com/news/read/3050825/kronologi-lengkap-joya-dibakar-hiduphidup-versi-warga-dan-polisi, Accessed on September, 19, 2020.
} 
Therefore social sanction (naked parade and vigilante) must be clearly regulated in criminal law, that those acts can be punished. Based on these reasons, this paper tries to explain social sanctions as a form of law violation from the perspective of human rights and criminal law.

Furthermore, this paper is doctrinal research, ${ }^{12}$ that study of law as in legislation. Therefore, this research's essential data is seconder in the form of primer law material, seconder law material, and tarsier law material as support material. ${ }^{13}$ Implementation of data collection through study literature by identification, inventory, and categorization. Data that already collected is analyzed qualitatively descriptive legal principles with the perspective of human rights and criminal law principles.

\section{B. Discussion}

\section{Social Sanction (Naked Parade and Vigilantism) in Human Rights Perspective}

International human rights, both the Islamic world and the international community in general, have recognized these things in its international agreement. The Islamic world affirms human rights (HAM) in the Cairo Declaration on Human Rights in Islam, August 5, 1990. This recognition is based on the maqasid sharia as the foundation of the development and enforcement of human rights. ${ }^{14}$ Because the maqasid shari'ah, it provides protection against five main things (1) protection to religion (hifdz ad din) that in the Islamic divinity values there is freedom of belief and worship without compulsion; (2) protection of life (hifdz an nafs), that Islam commands their people to do good and enforce justice among them, therefore Islam highly respects the right to life, thus prohibiting hostility that caused in damage or loss of the right to life; (3) Protection of reason (hifdz al aql), therefore Islam prohibits food and drink that can destroy reason, such as drugs, alcohol/liquor or others; (4) protection of property, that Islam encourages people working to obtain property in a lawful manner, and after that to spend in a lawful way also spend in Allah's rights from these assets (zakat, alms); (5) protection of heredity (hifdz an nasl), that Islam prohibits deed or action which is caused hereditary breakdown including the destruction of honor such as acts of gibah (gossip), pit against, calling using bad calls. ${ }^{15}$ The international community members of the United Nations affirmed human rights in the Universal

\footnotetext{
${ }^{12}$ Soetandyo Wignyo Soebroto, Hukum, Konsep dan Metode (Malang: Setara Press, 2013), 40.

${ }^{13}$ Soerjono Soekanto and Sri Pamudji, Penelitian Hukum Normatif (Suatu Tinjauan Singkat) (Jakarta:Raja Grafindo Persada, 2015), p. 33.

${ }^{14}$ Yaser Audah, Memahami Maqasid Syatiah: Peranan Maqasid Dalam Pembaharuan Isalm Kontemporari, Penterjemah Marwan Buchori A. Hamid (Selangor: PTS Islamika SDN.BHD, 2016), 47.

${ }^{15}$ Ahmad Al Mursi Husain Jauhar, Maqasid Syri'ah (Jakarta:Amzah, 2013), xiii.
} 
Declaration of Human Rights on December 10, 1948. One of the articles, namely Article 2, states, "Everyone has the right to life, liberty, and security of person." 16

Recognition of human rights in Indonesia before the international community, on August 17, 1945, in the Preamble of the 1945 Constitution from the first paragraph to the fourth paragraph. The first paragraph affirms, "That in fact, independence is the right of all nations and therefore colonialism over the world must be abolished because it is not in accordance with humanity and justice." This implies that freedom of life is the right of every individual and nation, but the implementation of life freedom in society must be based on human values and the justice value. The second paragraph, "And the struggle for the Indonesian independence movement has arrived at a happy moment safely prosperity escorting the Indonesian people to the front gates of the Indonesian state independence, which is independent, united, sovereign, just and prosperous." It contains the principle of recognition of the Indonesian people's rights in the Indonesian State formation. In other words, recognition of political rights. The third paragraph, "By the blessing of the grace of God Almighty and motivated by a noble desire, so that a free national life, the Indonesian people with this declare their independence." The meaning in this paragraph is recognition of God Almighty, which means giving human rights to religious. The Fourth paragraph stated that "According to which, in order to form a Government of the State of Indonesia that shall protect the whole people of Indonesia and the entire homeland of Indonesia, and in order to advance general prosperity, to develop the nation's intellectual life, and to contribute to the implementation of a world order based on freedom, lasting peace and social justice, Indonesia's National Independence shall be laid down in a Constitution of the State of Indonesia, which is to be established as the State of the Republic of Indonesia with the sovereignty of the people and based on the belief in the One and Only God, on just and civilized humanity, on the unity of Indonesia and on a democratic rule that is guided by the strength of wisdom resulting from deliberation/representation, to realize social justice for all the people of Indonesia." The fourth paragraph which emphasizes the purpose of this state in relation to human rights, that there is recognition and guarantee of human rights by the government in all aspects of life (the right to feel safe and comfortable, the right to economy, the right to education, the right to culture, the right to obtain justice, the right to argue, and others) for the realization of welfare. So, the principles of human rights based on the Preamble of the 1945 Constitution briefly are the liberty principles, non-discrimination, dignity, humanity and equity based on religious values.

\footnotetext{
${ }^{16}$ https://www.un.org/en/udhrbook/pdf/udhr_booklet_en_web.pdf, Accessed on December, 3, 2020.
} 
These principles have been elaborated in its body after the state has made amendments, the Body of 1945 the Republic of Indonesia Constitution, formulates the elaboration from Article 28A to Article 28J. However, before the amendment, the state has validated UUNo.39/1999 concerning Human Rights., which substance is based on these principles. Below, the author tries to explain the public's reaction in the form of a naked parade as illustrated by the cases above (introduction section), from the principles of the Indonesian human rights (liberty, non-discrimination, dignity, humanity, and equity) based on religious values.

The liberty principle or freedom that the state of law guarantees human freedom. Freedom here is defined as a freedom that provides social benefits, which are not relative, but the real social benefits. ${ }^{17}$ The basis for measuring this social benefit is action based on conscience, namely the highest values that underlie moral obligations. ${ }^{18}$ Giving social sanctions (naked parade and vigilantism) by the community is not based on moral obligations, which are sourced in the conscience that guides humans in acting, behaving, and speaking. This freedom has been normatively affirmed in the 1945 Constitution of the Republic of Indonesia, Article $28 \mathrm{~J}$, that freedom is limited by the human rights of others and freedoms are limited by law.

The principle of non - discrimination, this principle prohibits actions that restricting, harassing, and isolating based on differences in the clan, religion, race, ethnicity, group, social status, economic status, gender, language, and political beliefs. This principle applies to everyone, 1945 Constitution of the Republic of Indonesia jo Law No. 39/199 on Human Rights, guarantees the protection to the people who are discriminated, even though the person concerned made a mistake. This mistake must be proven before, proven in the judicial process, and according to the Human Rights Law, in the implementation of this judicial process, there must be a guarantee of an objective, honest, fair and impartial examination.

The dignity principle, this is an essential part of human rights, because shows that men have an existence, which can have a negative impact (the desire to dominate others), so that men need rasional attitude and social intheir actions. Pawel Lukow, said that human dignity is an important value in human rights, but to maintain it must be based on moral institutions, which limit humans to do actions. ${ }^{19}$ Laura Valentini, provides the dignity principle associated with Human Rights, that dignity includes inherent dignity and

\footnotetext{
17 James A. Stegenga, "J. S. Mill's Concept of Liberty and the Principle of Utility", Value Inquiry Journal 7, no. 4 (1973): 281-289, DOI: 10.1007/BF00208794.

18 Robert P. George, "John Stuart Mill and John Henry Newman on Liberty and Conscience", Saint Anselm Journal 10, no. 2 (2015): 40-36.

${ }^{19}$ Pawel Lukow, "A Difficult Legacy: Human Dignity as the Founding Value of Human Right “, Journal of Human Right Review 19, no. 3 (2018): 313-329, DOI: 10.1007/s12142-018-0500- 
dignity status. The first, things which is brought by humans from birth in the world and this cannot be taken away by anyone. The second point is that humans as subjects have sovereign authority (the subjects of sovereign authority). This subject is not only seen by humans as individuals but also humans as groups (corporate). This dignity status can be lost or taken away, when the individual or the group do an action that attacks inherent dignity. It is like an individual who molests or naked parade to another individual, then he will be punished so that his dignity status is lost because he does not have autonomy and authority anymore as a legal subject. The victim will also lose his dignity status because he gets the sanction that is deprived of his sovereign authority. ${ }^{20}$ So, social sanctions, both naked parade and vigilantism, rob human authority as a subject who has sovereignty in action.

The humanity principle, the word, indicates the character of human people, which is natural, based on the highest moral values, which often refers to the notions of philanthropy and altruism. Each nation's community has its own way to determine this principle. This principle is closely related to the dignity principle, which is clearly already in the Pancasila formula, especially the second principle, so that all Indonesian people, without exception, have a humanity character based on the moral values of the Indonesian nation. This principle point out human sovereignty, the meaning that men have freedom to act, but dignified sovereignty. Petters Anne, that individuals and state sovereignty must have a humanitarian function, the meaning that sovereignty must respect human rights, needs and security. Petter Anne said that this is the normative value of sovereignty, which is needed in human life as individuals and members of society. ${ }^{21}$ However, why the action of naked parade sanctions can occur, if it can be said that this human nature has been distorted, so that it fades, or even completely disappears, because of the individuals emotional character can affect the whole society and can trigger human rights violations.

The equity principle is not the same as justice, in terms of equity, there is a meaning which contains a concept of rights that cannot be revoked by anyone, while justice refers to proper and fair legal administration. ${ }^{22}$ Human rights are natural rights that cannot be revoked by any civil servant, including the state, therefore it must be guaranteed protection by the state, community and also individuals all over the world. Therefore the action of giving naked parade sanction to someone by the community, as a result, human rights are threatened and finally there is no justice. There is a constitutional guarantee to live, not to be tortured, to freedom of thought and conscience, to have religion, not to be enslaved, to be recognized as a person before the law, and

\footnotetext{
${ }^{20}$ Laura Valentini, "Dignity and Human Rights: A Reconceptualisation", Oxford Journal of Legal Studies 37, no. 4 (2017): 862-885, DOI: 10.1093/ojls/gqx011.

${ }^{21}$ Petters Anne, "Humanity as the A and \{Omega\} of Sovereignty", The European Journal of International Law 20, no. 3 (2019): 313 -544, DOI: 10.1093/ejil/chp026.

${ }^{22}$ B. A. Graner, Op. Cit., 1634 and 2528.
} 
not to be prosecuted on the retroactive legal basis. This is in Article 28 I of the 1945 Indonesian Constitution jo Articles 17, 18 and 19 of Law No. 39/1999 about Human Rights.

If these human rights principles are linked to the maqasid sharia, then this principle is identical because in this principle, it contains the principle of protecting the right of life (life) and reason. In addition, this principle also recognizes freedom in religion, action and expression of opinion or thoughts;

The social sanctions for naked parade and vigilante are based on human rights as a form of torture, both physically and psychologically, to make the perpetrator confess about the suspected act against the victim. The anti-torture convention that has been ratified by Indonesia with Law No. 5/1998 concerning Ratification of the Convention Against Torture And Other Cruel, Inhuman Or Degrading Treatment Or Punishment, Article 2 (2), which basically states that any circumstances for acts of torture are prohibited. This statement is no different from the substance of Article 28 I of the 1945 Indonesian Constitution jo Article 4 of Law No. 39/199 about Human Rights. The community has not legitimized this action because it is a culture of violence that contradicts human rights, and the state must prohibit these acts in a policy. ${ }^{23}$ In addition, this action, seen from the perspective of Pancasila, is very contradictory. Moreover, religious values as a source of goodness that animate/inspirit the next precepts explicitly state that the act is inhuman.

This section is the most crucial section of your article. The analysis and discussion should be clear and concise. The results should summarise (scientific) findings rather than providing data in great detail. Please highlight differences between your results or conclusions and the previous publications by other researchers.

\section{Social Sanctions (Naked Parade and Vigilante) in Criminal Law Perspective}

Community-Based Crime Prevention common in the world community, such as in the Japanese community, this activity is very effective for preventing street crime, but not for robbery. ${ }^{24}$ In Indonesia, this activity exists, its function is the same, as protecting the environment from crimes. However in reality, sometimes crime prevention of based communities leads to criminal acts, such as in Madura. They assume that they have the authority to punish the perpetrator. This happens because people have weak legal knowledge and

\footnotetext{
${ }^{23}$ Martin Maunga, at all, "Perspectives on Vigilantism in the Republic of Zimbabwe", Mediterranean Journal of Social Sciences 6, no. 5 (2015): 323-334, DOI: 10.5901/mjss.2015.v6n5s1p323.

${ }^{24}$ Anna Matsukawa, \& Shigeo Tatsuki, "Crime prevention through community empowerment: An empirical study of social capital in Kyoto", International Journal of Law, Crime and Justice 54, (2018): 89-101, DOI: 10.1016/j.ijlcj.2018.03.007.
} 
understanding, so they don't understand if the action is punishable. ${ }^{25}$ Before discussing vigilantism and nude parades in criminal law, in the below we will explain about criminal law as a framework.

Criminal law, which is meant in this paper, is substantive criminal law or material criminal law as mentioned in the introductory/preliminary section. Substantive criminal law/criminal law is a system consisting of a subsystem of the principle, the purpose of punishment, the criminal guidelines subsystem and the subsystem of the three main criminal law problems, namely criminal acts/crimes, mistakes or criminal liability and criminal. ${ }^{26}$ In criminal law, there are two fundamental principles that relate to the conditional imposition of punishment. That principle is the principle of legality and guilty, the first principle related with action or conduct which is an element of a crime or in latin actus reus, the second principle is related to criminal responsibility, which consists of internal (psychological) and external (wrong) elements. This is mens rea in Latin.

The principle of legality, as the basis to determining the right action, is punishable. There are several terms for mention this principle. Noela poena sine lege, (every conviction must be based on a criminal law), or Noela poena sine crimine, (every conviction is only applicable if the action of the person involved has been threatened with legal punishment), or Nullum crimen sine poena legal, (acts that have been threatened with punishment by law, when violated it can result in the imposition of penalty as threatened by law against the violator/offender).This principle contains basic norms, which function to protect human rights so that the state does not punish people arbitrarily. These basic norms are firstly, no person shall be punished in the absence of a bad mind No person shall be punished in the absence of a bad mind. This shows that there must be a will from the actor to realize the goal of the action, so that punishable. The second norm is that a person ought not to be punished in the name of a political community unless it can confidently be said that the community officially regards his conduct as warranting the criminal punishment at issue. ${ }^{27}$

The Penal Code regulates this principle in Article 1 paragraph (1) as follows:

(1) "No act shall be punished unless by virtue of a prior statutory penal provision." 28

\footnotetext{
${ }^{25}$ Wartiningsih, "Tindakan Main Hakim Sendiri (Eigenrichting), dalam terjadinya Pencurian Sapi Di Madura", Rechsidee 12, no. 2 (2017): 167-182, DOI: 10.21107/ri.v12i2.

${ }^{26}$ Barda Nawawi Arief, Tujuan dan Pedoman Pemidanaan:Perspektif Pembaharuan dan Perbandingan Hukum Pidana (Semarang: Pustaka Magister, 2015), 6.

${ }^{27}$ Petters Westen, "To Rules of Legality in Criminal Law", Law and Philosophy Journal 26, no. 3 (2007): 229-305, DOI: 10.007/s10982-006-007-7.

${ }^{28} \mathrm{https} / / /$ www.unodc.org/res/cld/document/idn/indonesian_penal_code_html/I.1_Criminal_Co de.pdf, January, 31, 2020.
} 
This article implies, among other things, that (1) the law must be based on a written law (lex scripta); (2) The legal prohibition is retroactive (lex pravia); (3) laws must be formulated in a detailed, accurate manner, the punishment is also explicit both in the form and duration of penalty (lex Certa); (4) Criminal law is strictly formulated and prohibits the use of analogy (lex sticta).

Individualization is the principle of criminal responsibility adopted in the criminal law system, so there is a term that he acts, he is responsible. In this principle there is a moral principle, that individual autonomy, ${ }^{29}$ but it is not exercised on their own accord. Autonomy is limited by the rules in force, to prevent crime.

The determination of criminal liability is a guilt principle (no crime without guilt $=$ Geen straf zonder schuld), or An action does not make the person guilty unless the mind is guilty of sin/Actus non facit reum, nisi mens sit rea. This principle is a psychological assessment of a person regarding their ability to be held accountable for actions that have been done, or what is called the internal element within the individual himself. This includes a person's maturity and a person's intellectual ability to distinguish between good and bad things or that person has common sense. On the other hand, this principle also assesses from the external (outer) element seen from the side of the action, the assessment from this side uses a normative measure, which automatically the legality principle becomes the basis for conducting an evaluation. ${ }^{30}$ To judge the act of naked parade or vigilantism as an act that violates the law, these two principles must be fulfilled.

Penalty social (naked parade and vigilantism) is based on the principle of legality that in the Penal Code or laws outside the Penal Code do not explicitly regulate the articles' formulation. Law enforcers in this case usually use Article 170 of the Penal Code, this article regulates about an act that can be punished is overt destruction of property or violence which causing in injury or serious injury or death. The formulation of this article does not explicitly state that vigilante action or naked parade can be punished, there should be a firm formula. Although in a vigilantcase such as the Zoya case, the judge applies Article 170 of the Penal Code in his decision. ${ }^{31}$ Although the article that apply to all perpetrators are the same, the sentences imposed are different. This matter bear in mind the principle of individualization.

The case of naked parade has penetrated into children, which has occurred in Sragen Regency who was suspected of stealing sandals, then the sandal's owner forces the child to take off his clothes and paraded around the village.

\footnotetext{
${ }^{29}$ Mouaid Al Qudah, "The moral Foundation of Criminal Liabilty", Intellectual Property Rights:Open Access 2, no. 3 (2014): 1-10, DOI: 10.4172/2375-4516.1000116.

${ }^{30}$ Kuswardani, Gilang Kartiko, "Asas Kesalahan dalam Hukum Pidana Pilar Perlindungan Hak Asasi Manusia", Prosiding Seminar Online \& Call For Paper, (2020), 11 - 20.

${ }^{31}$ Decision No 8 / pid.B / 2018 / Pn Bks, Decision No. 9 Bekasi District Court, Decision No 10 / pid.B / 2018 / Pn Bks, and Decision No 11 /pid.B / 2018 / Pn Bks.
} 
Although in the end, based on the Sragen District Court Decision No 66/Pid.Sus/2016/PN.Sgn, the perpetrator was given a sanctions based on Article $76 \mathrm{C}$ of Law No. 35/2014 concerning Amendments to Law No. 23/2002 on Child Protection. The criminal sanctions for violating these articles is regulated in Article 80, paragraph $1 .{ }^{32}$ This act is very inhumane, especially directed to children. It can be said a barbaric act and mains against the principle of prioritizing children's rights.

Currently, Indonesia is reforming its criminal law, so the authors argue that it is necessary to formulate social sanctions of naked parade and vigilante explicitly in criminal law as punishable acts. In other words, it is necessary to emphasize the criminalization of naked parade and vigilantism. One of measurement of criminalization that the action is hated by the community and incurs losses or incurs victims. ${ }^{33}$ Obviously, based on this measure that act make the public/community feel uncomfortable, and even disturbed the security and public order. However, that act is initially intended to maintain security and order in the community. Several other countries have formulated the act of vigilantism in their Penal Code, but the formulation of the naked parade is not yet in the Penal Code of other countries because the sanction for the naked parade is a typical sanction for the Indonesian people. Penal Code of other countries which formulate vigilantism action as a punishable act, there are the Serbian Penal Code in Article 330, the Albanian Penal Code in Article 227 as follows:

Penal Code of the Republic of Serbia

Vigilantism

Article 330

(1) Whoever arbitrarily assumes a right for himself or a right he considers that he is entitled to, shall be punished by a fine or imprisonment of up to six months to five years.

(2) Whoever commits the offence referred to in paragraph 1 of this article for another, shall be punished by the penalty stipulated for such offence. (3) If the offence referred to in paragraphs 1 and 2 is committed to the detriment of citizens, the prosecution is instigated by private action. ${ }^{34}$

Penal Code of the Republic of Albania

Vigilantism

Article 227

\footnotetext{
32 Septianto Pamungkas, Kuswardani, "Pelaksanaan Sanksi Arak Bugil Oleh Masyarakat Perspektif Undang - Undang Perlindungan Anak," Thesis, Universitas Muhammadiyah Surakarta.

${ }^{33}$ Barda Nawawi Arief, Bunga Rampai Kebijakan Hukum Pidana: Perkembangan Penyusunan Konsep KUHP Baru (Jakarta : Kencana, 2017), 32.

${ }^{34}$ https://www.legislationline.org/download/id/5480/file/Serbia_CC_am2012_en.pdf,

Accessed on November, 18, 2020.
} 
The exercise of a right by a person who retains the right or he thinks he retains the right which is not recognized by the other person without addressing to the competent State body constitutes criminal contravention and is punishable by a fine or up to three months of imprisonment. ${ }^{35}$

This firm formulation is needed so that people can know and understand that not all actions based on living legal values are lawful. There are acts according to living law as acts that snatch other human rights and can be punished.

\section{Conclusion}

Social sanctions in the form of naked parade and vigilantism as acts which is break human rights, whether directed at adults or children, even though the act grew and was born from the local community. However, according to Law no. 26 of 2000 regarding the Human Rights Court, that this act is not a gross human rights violation. These acts are ordinary criminal act or criminal offense. These violations are not under the authority of the human rights court, but are under the authority of the criminal court.

Penal Code and/or criminal law regulations outside of the Penal Code do not formulate explicitly that acts, even though in some cases of naked parade/vigilantism with adult perpetrators, judges make decisions based on Article 170 of Penal Code. Perpetrators of naked parade against children, the punishment is based on Law no. 35/2014 concerning Amendments to Law No. 23/2002 about Child

Thus, it is necessary to formulate vigilante and naked parade as an act that can be punished in a law, or included in the Penal Code will come. This is intended so that people know that not all actions based on the values that live in society are valid. Or another alternative is to raise awareness to the public by law enforcement officials (police, prosecutors) or academics or community organizations that the act is a criminal act.

\section{References}

Al Qudah. "Mouaid The moral Foundation of Criminal Liabilty", Intellectual Property Rights: Open Access Journal 2, no. 3, 2014: 1-10, DOI: 10.4172/2375-4516.1000116.

Anne, Petters. "Humanity as the A and \{Omega\} of Sovereignty", The European Journal of International Law 20, no. 3, 2019: 313 -544, DOI: 10.1093/ejil/chp026.

Arief, Barda Nawawi. Bunga Rampai Kebijakan Hukum Pidana: Perkembangan Penyusunan Konsep KUHP Baru. Jakarta: Kencana, 2017.

\footnotetext{
35 https://www.legislationline.org/download/id/8235/file/Albania_CC_1995_am2017_en.pdf, Accessed on November, 18, 2020, Accessed on November, 18, 2020.
} 
Arief, Barda Nawawi. Tujuan dan Pedoman Pemidanaan:Perspektif Pembaharuan dan Perbandingan Hukum Pidana. Semarang: Pustaka Magister, 2015.

Asmarawati, Tina. "Perspektif Hukum Dalam Main Hakim Sendiri", Jurnal Nurani Hukum 3, no. 1, 2020: 45-57.

Audah, Yaser. Memahami Maqasid Syatiah: Peranan Maqasid Dalam Pembaharuan Isalm Kontemporari, Penterjemah Marwan Buchori A. Hamid. Selangor: PTS Islamika SDN.BHD, 2016.

Decision No 8 / pid.B / 2018 / Pn Bks, Decision No. 9 Bekasi District Court, Decision No 10 / pid.B / 2018 / Pn Bks, and Decision No 11 /pid.B / 2018 / Pn Bks.

Garner, A. Bryan. Black Law Dictionary. Paul Mint: West Publishing, 2004.

Geiran, Vivian ., Durnescu, Ioan. Implementing Community Sanctions and Measures. Europe: the Directorate General Human Rights and Rule of Law, 2019.

George, Robert P. "John Stuart Mill and John Henry Newman on Liberty and Conscience", Saint Anselm Journal 10, no. 2, 2015: 40-36

Hass, Nicole E. "Public support for vigilantism, confidence in police and police responsiveness", Policing and Society Journal 24, no. 2, 2014: 224-41, DOI: 10.1080/10439463.2013.784298.

https://www.kanalinspirasi.com/diduga-mesum-dengan-bidan-bersuamioknum-polisi-diarak-keliling-kampung/, Accessed on September, 19, 2020.

https://www.legislationline.org/download/id/5480/file/Serbia_CC_am2012_ en.pdf, Accessed on November, 18, 2020.

https://www.legislationline.org/download/id/8235/file/Albania_CC_1995_a m2017_en.pdf, Accessed on November, 18, 2020, Accessed on November, 18, 2020.

https://www.liputan6.com/news/read/3050825/kronologi-lengkap-joyadibakar-hidup-hidup-versi-warga-dan-polisi, Accessed on September, 19, 2020.

https://www.unodc.org/res/cld/document/idn/indonesian_penal_code_html/I.

1_Criminal_Code.pdf, January, 31, 2020.

Jauhar, Husain., Al Mursi, Ahmad. Maqasid Syri'ah, Jakarta: Amzah, 2013.

Klingele, Cecelia. "Rethinking The Use Of Community Supervision", Journal of Criminal Law and Criminology 103, no. 4, 2013: 1015-1070, DOI: $10.2139 / \mathrm{ssrn} .2232078$.

Kuswardani., Kartiko, Gilang. "Asas Kesalahan dalam Hukum Pidana Pilar Perlindungan Hak Asasi Manusia". Prosiding Seminar Online \& Call For Paper, 2020.

Law No 1 of 1946 Concerning Regulation of Criminal Law.

Law No. 39 of 1999 Concerning Human Rights. 
Lukow, Pawel. "A Dificult Legacy :Human Dignity as the Founding Value of Human Right “. Journal of Human Right Review 19, no. 3, 2018: 313329, DOI: $10.1007 / \mathrm{s} 12142-018-0500-\mathrm{z}$

Matsukawa, Anna., Shigeo Tatsuki. "Crime prevention through community empowerment: An empirical study of social capital in Kyoto", International Journal of Law, Crime and Justice 54, 2018: 89-101, DOI: 10.1016/j.ijlcj.2018.03.007.

Maunga, Martin et all, "Perspectives on Vigilantism in the Republic of Zimbabwe", Mediterranean Journal of Social Sciences, 6, no. 5, 2015: 323-334, DOI: 10.5901/mjss.2015.v6n5s1p323.

Rompis, Tonny. "Kajian Sosiologi Hukum Tentang Menurunnya Kepercayaan Masyarakat Terhadap Hukum Dan Aparat Penegak Hukum Di Sulawesi Utara". Jurnal Lex Crimen 4, no. 8, 2015: 166176.

Septianto, Pamungkas.. Kuswardani, "Pelaksanaan Sanksi Arak Bugil Oleh Masyarakat Perspektif Undang-Undang Perlindungan Anak," Thesis, Universitas Muhammadiyah Surakarta.

Shttp://harianumumsinarpagi.com/2018/04/13/korban-persekusi-bocahberusia-12-tahun-di-bekasi-dipukuli-lalu-di-arak-bugil-lantarandituding-curi-jaketr/, Accessed on September, 19, 2020.

Silke, Andrew. "Dealing Vigilantism Dealing with Vigilantism: Issues and Lessons for the Police". The Police Journal: Theory, Practice and Principles 74, 2001: 120-133, DOI: 10.1177/0032258X0107400204.

Soebroto, Wignyo. Soetandyo. Hukum, Konsep dan Metode. Malang: Setara Press, 2013.

Soekanto., Sri Pamudji. Penelitian Hukum Normatif (syuatu tinjauan singkat). Jakarta: Raja Grafindo Persada, 2015.

Stegenga, James A. "J. S. Mill's Concept of Liberty and The Principle of Utility". Value Inquiry Journal 7, 1973: 281-289, DOI: 10.1007/BF00208794.

Universal Declaration of Human Rights.

Valentini, Laura. "Dignity and Human Rights : A Reconceptualisation", Oxford Journal of Legal Studies 37, no. 4, 2017: 862-885, DOI : 10.1093/ojls/gqx011.

Wartiningsih. "Tindakan Main Hakim Sendiri (Eigenrichting), dalam terjadinya Pencurian Sapi Di Madura", Rechsidee 12, no. 2, 2017: 167182, DOI: $10.21107 /$ ri.v12i2.

Westen, Petters. "To Rules of Legality in Criminal Law, Law and Philosophy Journal 26, no. 3, 2007: 229-305, DOI: 10.007/s10982-006-007-7.

Wiesburd, David. "Vigilatism as Community Social Control : Developing a Quatitative Criminological Model". Journal of Quatitative Criminology 4, 1988: 37-153, DOI: 10.1007/BF01062870. 